\title{
Changes in Learning Style Preferences of Physical Education Students
}

Ceyhun AlemdaĞ ${ }^{1}$

$\approx$ Identification of learning styles is one way of contributing to a more efficient teaching process, and it helps teachers choose an effective teaching strategy. This study reports a three-year process to explain the change in the learning styles of physical education students. It also involves an assessment of the overall academic achievement of physical education students based on their learning style preferences throughout this process. Forty-one physical education students, $41.5 \%$ of whom were female, comprised the sample. The study used a longitudinal study/panel study design to observe the time-dependent variation of learning styles. The data were collected using the Kolb Learning Style Inventory 3 and analysed using a Chi-Squared ( $\left.\chi_{2}\right)$ test, Kruskal-Wallis H test, and MannWhitney $U$ test. The results of the analysis showed that the curriculum of the PE teaching department did not lead to a change in the learning styles of students studying in this department. Additionally, the overall academic achievement of the physical education students did not vary for the first (Semester 3 ) and second measurements (Semester 5) based on their learning style preferences. However, for the third measurement (Semester 7), learning style preferences had differing effects on their academic achievement.

Keywords: study process, learning style, longitudinal study, teacher candidate 


\section{Spremembe v izbranih učnih stilih študentov športne vzgoje}

Ceyhun AlemdaĞ

$\propto$ Določitev učnih stilov je eden izmed načinov, ki prispeva k učinkovitejšemu procesu poučevanja in pomaga učiteljem pri izbiri učinkovite strategije poučevanja. Študija pojasnjuje spremembe učnih stilov študentov športne vzgoje skozi triletno obdobje in vključuje oceno njihovega splošnega akademskega uspeha na osnovi izbranih učnih stilov v tem procesu. Vzorec je obsegal 41 študentov športne vzgoje, od katerih je bilo $41,5 \%$ žensk. Namen longitudinalne/panelne študije je bil spremljanje kronološke spremembe učnih stilov. Podatki so bili zbrani s pomočjo Kolbovega modela učnih stilov 3 in analizirani s hi-kvadrat testom $\left(\chi_{2}\right)$, Kruskal-Wallisovim H-testom, in Mann-Whitneyjevim U-testom. Rezultati analize so pokazali, da se zaradi kurikuluma oddelka za športno vzgojo niso spremenili učni stili študentov tega oddelka. Prav tako se njihov splošen akademski uspeh ob izbranih učnih stilih ni razlikoval pri prvem (3. semester) in drugem (5. semester) merjenju, pri tretjem merjenju pa so se pokazali različni vplivi izbranih učnih stilov na akademske dosežke študentov športne vzgoje.

Ključne besede: študijski proces, učni stili, longitudinalna študija, študentje pedagoških smeri 


\section{Introduction}

\section{Literature Review}

The extent to which students make use of teaching practices varies based on their individual characteristics (Felder \& Brent, 2005; Kuzgun \& Deryakulu, 2006). This variation is revealed by associating the content to be learned with that previously learned and structuring it in the mind (Connell \& Franklin, 1994; Felder \& Brent, 2005; G. H. Hein, 1991; Jonassen, Davidson, Collins, Campbell, \& Haag, 1995; Yaşar, 1998). Thus, teachers are expected to take into account students' characteristics and needs while deciding on many topics including which method, approach or strategy to use, how to organise the content of courses, or which measurement and assessment approach to use (Kuzgun \& Deryakulu, 2006). Learning styles refer to an approach of perception, processing, and interpretation that occurs as an individual difference (Kolb \& Kolb, 2005). Learning styles provide many clues as to students' learning characteristics and provide teachers with background information on how to plan the teaching process. Although the results of research on which learning style is more functional in educational processes are not consistent, learning styles are generally known to affect learning and facilitate the acquisition of certain types of learning outcomes (Şimşek, 2006).

Research on learning styles in the field of PE and sports has mostly used a cross-sectional survey design and associated learning styles with independent variables including gender, grade level, sportsmanship, education level, the field of graduation, and academic achievement (Alemdağ et al., 2018; Alemdağ et al., 2016; Alemdağ \& Öncü, 2015; Çağlayan, 2011; Çelik \& Şahin, 2011; Coker, 1996; Ristori et al., 2011; Yalız \& Erişti, 2010). Considering the methodological approach of previous research, researchers generally use a cross-sectional, not a longitudinal design as a way of investigating learning styles. The difference in how researchers deal with the issue stems from their conception of learning styles as a »structure« or the way they think learning styles are related to a "process «. It is assumed that it is challenging to intervene if learning styles are seen as a structure; however, it is much easier if they are seen as a process. An interaction between content and practice is accepted to exist if learning styles are regarded as both a structure and a process (Şimşek, 2006).

Researchers outside the field of sports have examined the change in students' learning styles over time (Busato et al., 1998; Cimermanová, 2018; Pinto \& Geiger, 1991; Rakoczy \& Money, 1995). However, the field of sports has failed to conduct studies observing changes in the learning styles of students. 
Accordingly, this study seems to be of importance in observing the learning characteristics of PE students and thereby helping sports educators take some action.

This study is concerned with changes in students' learning styles in departments of PE and sports teaching that teach mainly applied courses as well as theoretical courses. Research on learning styles suggests that students have higher academic achievement in programmes that are designed taking into consideration the learning characteristics of students (Birrell et al., 1985; Burns et al., 1998; Fan et al., 2015; Gökalp, 2013; Hein \& Budny, 200o; Horton \& Oakland, 1997; Komarraju et al., 2011; Reynolds \& Gerstein, 1992; Uzuntiryaki, 2007; Yazıc1lar \& Güven, 2009). Against this background, this study analysed the overall academic achievement levels of PE students based on their learning style preferences.

\section{Research Questions (RQ):}

RQ1. Is there a significant association between the learning style preferences of PE students and the teaching process in which they are involved?

RQ2. Does PE students' overall academic achievement differ based on their learning style preferences (for each measurement/semester)?

\section{Method}

\section{Model}

The study used a longitudinal design. The status and characteristics of the cohort were identified through a tracking approach. The sample was selected by cluster sampling among individuals who shared common characteristics and experiences (Ekiz, 2009). The data were collected from students studying at the Department of Physical Education and Sports Teaching at Karadeniz Technical University. Repeated measurements were performed on the same respondents in certain intervals over time in line with the principles of longitudinal studies (Figure 1) (Cohen et al., 2000; Fraenkel \& Wallen, 2008). Measurements were repeated three times at the beginning, middle, and end of the study. The first measurement (Time 1) was performed in the fall term of the 2015/2016 academic year (at the beginning of Semester 3 ) and the last two (Time 2 and Time 3 ) in one-year intervals. 


\section{Figure 1}

A sample for developmental research. Adapted from Research methods in education (p. 175), L. Cohen et al., 200o, Routledge Falmer, Taylor \& Francis Group.

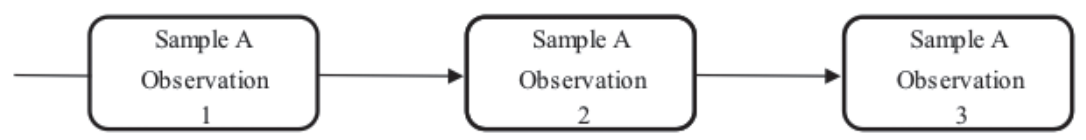

The data were collected using the questionnaire method, which is frequently used for surveying (Erkuş, 2009). The questionnaire forms were administered by the researcher after obtaining informed written consents.

\section{Sample}

The sample consisted of $41 \mathrm{PE}$ and sports students, among whom $41.5 \%$ were female (the last measure was performed on 40 students due to the withdrawal of a student). First-year students were not involved in the measurements since they had just started university and were adjusting to a new level of education.

\section{Instruments}

The data were collected using the original Kolb Learning Style Inventory 3 (KLSI-3) developed by Kolb, Rubin, and McIntyre (1971). The inventory that was developed to identify preferred learning styles was adapted to Turkish by Evin Gencel (2007). It consists of 12 sentence-completion items that ask respondents to rank four sentence endings from 1 (least like me) to 4 (most like me). Item scores (ranging from 18 to 48 ) result in four different values. Each value represents one learning mode of the learning cycle (concrete experience-CE, abstract conceptualisation- $\mathrm{AC}$, reflective observation-RO, and active experimentation-AE). Subsequently, combination scores are computed. Combination scores range from -36 to +36 . Two combination scores measure an individual's learning style preference, that is, abstractness over concreteness (AC-CE) and action over reflection (AE-RO). Two combination scores are placed on the horizontal and vertical lines ( $\mathrm{x}$-axis and $\mathrm{y}$-axis) in Kolb's coordinate system (Devid A Kolb, 1999), and the intersection of the scores represents an individual's learning style. Cronbach's alpha coefficient of the learning style dimensions was found to range from .71 to $.80(n=320)$ in Evin Gencel's study 
(2007). In this study, the value of the Cronbach's alpha coefficient was found to range from .75 to $.86(n=41)$ using the data collected in the first measurement.

The overall academic achievement of the respondents was determined by considering their grade point average (GPA) in each measurement term (at the beginning of Semesters 3, 5, and 7).

\section{Data Analysis}

A frequency analysis was performed to determine missing or incorrect data, but no missing or incorrect data were found. The data were analysed by SPSS statistics 22.0 using the Chi-Squared $\left(\chi^{2}\right)$ test, Kruskal-Wallis $\mathrm{H}$ test and Mann-Whitney U test.

\section{Results}

The study first aimed to determine whether the curriculum of the PE teaching department caused a change in the learning styles of students studying in this department $\left(\mathrm{RQ}_{1}\right)$. The frequency and percentage distributions of the $\mathrm{PE}$ students were analysed to determine their learning style preferences. Table 1 shows the $\chi^{2}$ test results of the measurements performed in three different time intervals.

Table 1

The distribution of learning styles by time

\begin{tabular}{lcccccc}
\hline & & \multicolumn{4}{c}{ Learning Styles } & \multirow{2}{*}{ Total } \\
\cline { 3 - 6 } & & Diverging & Assimilating & Converging & Accommodating & \\
\hline Time 1 & $\mathrm{n}(\%)$ & $18(43.9)$ & $11(26.8)$ & $7(17.1)$ & $5(12.2)$ & $41(100)$ \\
Time 2 & $\mathrm{n}(\%)$ & $10(24.4)$ & $13(31.7)$ & $7(17.1)$ & $11(26.8)$ & $41(100)$ \\
Time 3 & $\mathrm{n}(\%)$ & $11(27.5)$ & $8(20)$ & $9(22.5)$ & $12(30)$ & $40(100)$ \\
\hline Total & $\mathrm{n}(\%)$ & $39(32)$ & $32(26.2)$ & $23(18.9)$ & $28(23)$ & $122(100)$ \\
\hline
\end{tabular}

Note. $\chi^{2}=7.5, d f=6, p=.28$

Considering the $\chi^{2}$ test results on learning styles, the respondents with assimilating and converging learning styles had similar/close ratios for the three measurements. The ratio of those with diverging and accommodating learning styles changed more markedly in the second and third measurements in comparison to the first measurement (Figure 2). The ratio of those with a diverging learning style was $43.9 \%$ in the first measurement but dropped to $24.4 \%$ and $27.5 \%$ in the second and third measurements, respectively. The ratio of those 
with an accommodating learning style was $12.2 \%$ in the first measurement, but this ratio rose to $26.8 \%$ and $30 \%$ in the second and third measurements, respectively (Table 1). This difference found in learning styles in different time intervals was not statistically significant $\left(\chi^{2}(6)=7.5, p>.05\right)$.

\section{Figure 2}

The cycle of learning of PE students

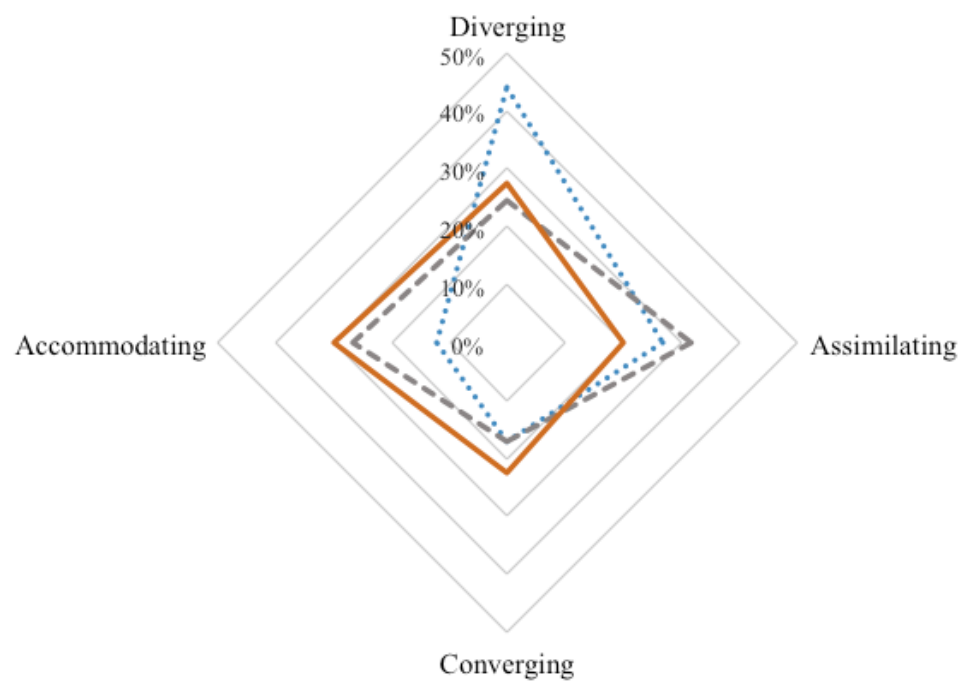

…... time $1 \quad---\cdot$ time $2 \longrightarrow$ time 3

RQ2 asked whether PE students' overall academic achievement differed based on their learning style preferences throughout this process. Table 2 presents the Kruskal-Wallis $\mathrm{H}$ test results on the overall academic achievement of PE students with different learning styles.

Table 2

The distribution of overall academic achievement according to learning styles

\begin{tabular}{llcccccc}
\hline & Learning Styles & $\boldsymbol{n}$ & Mean Rank & df & $\chi^{2}$ & $\boldsymbol{p}$ & Significance \\
\hline \multirow{2}{*}{ Time 1 } & Diverging (Di) & 18 & 16.11 & & & & \\
& Assimilating (As) & 11 & 23.77 & & & & \\
& Converging (Co) & 7 & 23.57 & 3 & 6.09 & .11 & - \\
& Accommodating (Ac) & 5 & 28.9 & & & & \\
\hline
\end{tabular}




\begin{tabular}{llcccccc}
\hline & Learning Styles & $\boldsymbol{n}$ & Mean Rank & df & $\chi^{2}$ & $\boldsymbol{p}$ & Significance \\
\hline \multirow{2}{*}{ Time 2 } & Diverging (Di) & 10 & 19.95 & & & & \\
& Assimilating (As) & 13 & 16.65 & & & & \\
& Converging (Co) & 7 & 25.5 & 3 & 3.58 & .31 & - \\
& Accommodating (Ac) & 11 & 24.23 & & & & \\
\hline \multirow{2}{*}{ Time 3 } & Diverging (Di) & 11 & 16.09 & & & & \\
& Assimilating (As) & 8 & 14.31 & & & & \\
& Converging (Co) & 9 & 22.61 & 3 & 7.93 & .04 & As-Ac \\
& Accommodating (Ac) & 12 & 27.08 & & & & \\
\hline
\end{tabular}

Note. $p<.05$.

The result of the analysis showed that the overall academic achievement of PE students did not differ based on their learning style preferences for the first $\left(\chi^{2}(d f=3, n=41)=6.09, p>.05\right)$ and second $\left(\chi^{2}(d f=3, n=41)=3.58, p>.05\right)$ measurements.

For the third measurement, however, the participants' academic achievement differed based on their learning style preferences $\left(\chi^{2}(d f=3, n=40)=7.93\right.$, $p<.05)$. This result demonstrated that preferred learning styles had different effects on the academic achievement of the PE students. The mean ranks of the groups showed that the PE students with an accommodating learning style enjoyed the highest academic achievement, and they were followed by those with convergence, divergence, and assimilations in order. The source of the significant difference between the learning styles was analysed by the paired combinations of the groups (using the Mann-Whitney U test). Accordingly, the PE students with an accommodating learning style enjoyed higher academic achievement than assimilators did. According to the sequential measurements, accommodators enjoyed high academic achievement in all three measurements, while the academic achievement of assimilators showed a downward trend starting with the first measurement.

\section{Discussion}

This study found that although there were some variations in the PE students' learning style preferences in the measurements made in different time intervals, these variations were not statistically significant. This result means that learning styles are more stable for PE students to change in time. Although a considerable volume of cross-sectional research has found significant differences among the grades of an education level (high school, university etc.) in terms of preferred learning styles (Alemdağ \& Öncü, 2015; Baldwin \& Reckers, 1984; 
Cavas, 2010; Evin Gencel \& Köse, 2011; Katranc1 \& Bozkuş, 2014; Kurbanoğlu \& Akkoyunlu, 2008; Özdemir \& Kesten, 2012), research on the same groups has reported that the change in preferred learning styles is not very marked (Busato et al., 1998; Pinto \& Geiger, 1991; Rakoczy \& Money, 1995). Considering previous research reporting a significant difference among grades in terms of preferred learning styles, researchers used a cross-sectional survey design. Indeed, they noted that it is inconvenient to use cross-sectional data to explain a longitudinal phenomenon (Pinto \& Geiger, 1991). In this study, therefore, the results derived from the measurements performed on the same respondents at different intervals had similar characteristics to the results of other longitudinal research.

A review of literature in the field of sports (sports sciences faculties, sports high schools, student-athletes, etc.) (Alemdağ et al., 2016, 2018; Alemdağ \& Öncü, 2015; Çelik \& Şahin, 2011; Ristori et al., 2011; Yalız \& Erişti, 2010) showed that diverging and assimilating were the most preferred learning styles while accommodating was the least preferred learning style. Considering the distribution of learning styles in the sum of three measurements (see Table 1) in this study, the students mostly had diverging and assimilating learning styles. This result was consistent with research on learning styles in the field of sports (unlike other research reports, accommodating was the least preferred learning style for the respondents in this study). After taking sports into consideration as a defining feature, it seemed that the similarity between the results was due to the measurements performed on students with similar qualifications. Even if students are involved in different levels of education (high school, university, etc.), the results are close due to their shared characteristics, mainly including sports. Alemdağ et al. (2018) argued that it would be expedient to pay attention to group work in practical courses and give feedback during sports practice in line with the general characteristics of the diverging learning style. They emphasised the importance of active participation within the group in terms of students' social and emotional development and noted that feedback would facilitate practising and remembering sports skills. Although the dominant learning style of the PE students was diverging, it will be useful to know what the approaches that are suitable for other learning styles are. This is because knowing about the dominant learning style of the group in question does not mean those with other learning styles may be neglected. In this sense, considering the characteristics of those with the assimilating learning style, it was emphasised that they are highly competent in putting very comprehensive knowledge into a short and logical form.

Additionally, the theory has a more logical robustness than practice for them, and they are interested in ideas and abstract concepts more than they are 
interested in people (Kolb \& Kolb, 2005). Individuals with the converging learning style are highly competent in finding practical implementations for ideas and theories, they have problem-solving skills and prefer dealing with technical tasks and problems rather than social and interpersonal issues (Kolb \& Kolb, 2005). Based on all these characteristics related to learning styles, there is a clear need for teachers to focus on these features that represent learning styles.

In the search for an answer to RQ2, the overall academic achievement levels of the PE students were analysed at different intervals in relation to their learning style preferences. The primary purpose of this study for analysing $\mathrm{PE}$ students' academic achievement based on their learning styles was not to reveal which learning style is more useful or helpful, but rather to examine the compatibility or incompatibility between learning style preferences and academic achievement. The result of the analysis showed that the dominant learning styles of the PE students were diverging and assimilating, considering the total of the three measurements. However, those with an accommodating learning style enjoyed the highest academic achievement in the measurements taken in three different intervals. This incompatibility between the PE students' dominant learning styles and academic achievement levels may mean attention was not paid to PE students' learning style preferences at the beginning and end of the programme. In other words, this may suggest that the PE students' dominant learning styles were not identified, and lecturers did not design their semester or annual syllabus in line with these learning styles. A similar incompatibility was previously reported in a study on sports high school students (Alemdağ et al., 2018). The fact that students with an accommodating learning style have high academic achievement may suggest that courses are mostly taught in line with the learning characteristics of these students. Kolb (1984) described accommodators as individuals who engage in new experiences, plan frequently, seek opportunities, take risks and adapt to changing circumstances. Additionally, accommodators prefer to work with others and pay attention to effectively communicate with athletes, coaches and other colleagues (Stradley et al., 2002).

\section{Conclusion}

The primary results of the study showed that the learning styles of the PE students were more stable in time based on the measurements performed at different intervals. This situation suggests that when PE students' learning styles are identified, one can be informed about their learning characteristics for a specified period (2-3 years). This period may be regarded as reasonable, considering the duration of the PE teaching programme. Thus, lecturers or 
those who do not manage teaching programmes will not have to apply a very strict programme to identify PE students' learning styles.

The secondary result of the study showed an incompatibility. The dominant learning styles of the PE students were diverging and assimilating, considering the sum of the three measurements. However, the highest academic achievement was obtained by convergers and accommodators in three different intervals.

Lecturers should be willing to identify students' learning characteristics before designing their semester syllabus so that they can adopt an effective teaching strategy. Provided that students with different learning characteristics are not disregarded, a course design conforming to dominant learning styles will result in a more effective and efficient education process. Especially in PE and sports departments, which teach both theoretical and practical courses, it is useful for lecturers to frequently review their teaching strategies to keep up with students' learning characteristics.

Future research may adopt a qualitative approach to investigate whether courses are taught in keeping up with the learning characteristics of students. If any relevant compatibility or incompatibility is discovered, more appropriate measures may be taken regarding the education and teaching process of $\mathrm{PE}$ students.

\section{References}

Alemdağ, C., Alemdağ, S., \& Özkara, A. B. (2018). The analysis of sports high school students' learning styles in terms of overall academic success. Education and Science, 43(195), 269-278. https:// doi.org/10.15390/EB.2018.7327

Alemdağ, C., Kalkavan, A., Alemdağ, S., \& Özkara, A. B. (2016). The learning styles of student athletes according to alma mater and academic achievement. International Journal of Science Culture and Sport, 4 (Special Issue-1), 146-155.

Alemdağ, C., \& Öncü, E. (2015). Pre-service physical education teachers according to Kolb's model of learning style. Journal of Subject Teaching Research, 1(1), 1-12. http://dergipark.ulakbim.gov.tr/aleg/ article/view/5000105292

Baldwin, B. A., \& Reckers, P. M. J. J. (1984). Exploring the role of learning style research in accounting education policy. Journal of Accounting Education, 2(2), 63-76. https://doi. org/10.1016/0748-5751(84)90006-X Birrell, H. V, Phillips, C. J., \& Stottc, D. H. (1985). Learning style and school attainment in young children: a follow-up study. School Psychology International, 6, 207-218. Burns, D. E., Johnson, S. E., \& Gable, R. K. (1998). Can we generalize about the learning style characteristics of high academic achievers? Roeper Review, 20(4), 276-281. 
https://doi.org/10.1080/02783199809553907

Busato, V. V., Prins, F. J., Elshout, J. J., \& Hamaker, C. (1998). Learning styles: A cross-sectional and longitudinal study in higher education. British Journal of Educational Psychology, 68, 427-441. https:// doi.org/10.1111/j.2044-8279.1998.tbo1302.x

Çağlayan, H. S. (2011). The investigation of academicians' learning styles in school of physical education and sports in Turkey. Educational Research and Reviews, 6(3), 326-333. http://search. ebscohost.com.proxy-ub.rug.nl/login.aspx?direct=true $\& \mathrm{db}=$ eric $\& A \mathrm{~N}=\mathrm{EJ} 923665 \&$ site $=$ ehostlive\&scope $=$ site\% 5 Cnhttp://www.academicjournals.org/ERR/PDF/Pdf 2011/Mar/Caglayan.pdf Cavas, B. (2010). A study on pre-service science, class and mathematics teachers' learning styles in Turkey. Science Education International, 21(1), 47-61.

Çelik, F., \& Şahin, H. (2011). Beden eğitimi ve spor öğretmenliği öğretmen adaylarının cinsiyet ve öğrenim gördükleri sınıf düzeyi bakımından öğrenme stillerinin incelenmesi (MAKÜ örneği) [Investigation of learning styles of pre-service physical education and sport teachers according to gender and graduate levels (MAKU sample)]. Dokuz Eylül Üniversitesi Buca Eğitim Fakültesi Dergisi, $31,23-38$.

Cimermanová, I. (2018). The effect of learning styles on academic achievement in different forms of teaching. International Journal of Instruction, 11(3), 219-232. https://doi.org/10.12973/iji.2018.11316a Cohen, L., Manion, L., \& Morrison, K. (2000). Research methods in education (5th ed.). Routledge Falmer, Taylor \& Francis Group.

Coker, C. (1996). Accommodating students' learning styles in physical education. Journal of Physical Education, Recreation \& Dance, 67(9), 66-68.

Connell, T., \& Franklin, C. (1994). The Internet: Educational issues. Library Trends, 42(4), 608-625. https://www.ideals.illinois.edu/bitstream/handle/2142/7928/librarytrendsv42i4d_opt.pdf?sequence=1 Ekiz, D. (2009). Bilimsel araştırma yöntemleri [Scientific research methods] (2nd ed.). Anı Yayıncılık. Erkuş, A. (2009). Davranış bilimleri için bilimsel araştırma süreci [Scientific research process for behavioral sciences] (2nd ed.). Seçkin Yayıncılik.

Evin Gencel, İ. (2007). Kolb’un deneyimsel öğrenme kuramına dayalı öğrenme stilleri envanteri-III’ü Türkçe’ye uyarlama çalışması [Adapting Kolb’s Learning Styles Inventory-III based on experiential learning theory into Turkish]. Dokuz Eylül Üniversitesi Sosyal Bilimler Enstitüsü Dergisi, 9(2), 120-139.

Evin Gencel, İ., \& Köse, A. (2011). Relationship between the prospective science teachers' learning styles, learning and study strategies, and self-efficacy beliefs in science teaching. Journal of Theory and Practice in Education, 7(2), 311-333. https://doi.org/10.17244/eku.86666 Fan, K. K., Xiao, P., \& Su, C. H. (2015). The effects of learning styles and meaningful learning on the learning achievement of gamification health education curriculum. Eurasia Journal of Mathematics, Science \& Technology Education, 11(5), 1211-1229. https://doi.org/10.12973/eurasia.2015.1413a Felder, R. M., \& Brent, R. (2005). Understanding student differences. Journal of Engineering Education, 94(1), 57-72. https://doi.org/10.1002/j.2168-9830.2005.tboo829.x

Fraenkel, J. R., \& Wallen, N. E. (2008). How to design and evaluate research in education (7th ed.). 
McGraw-Hill Higher Education.

Gökalp, M. (2013). The effect of students' learning styles to their academic success. Educational Research and Reviews, 8(17), 1634-1641. https://doi.org/10.5897/ERR2013.1575

Hein, G. H. (1991). Constructivist learning theory. In The museum and the needs of people - CECA (International Committee of Museum Educators) - Conference.

Hein, T. L., \& Budny, D. D. (200o). Styles and types in science and engineering education. In International Conference on Engineering and Computer Education.

Horton, C. B., \& Oakland, T. (1997). Temperament-based learning styles as moderators of academic achievement. Adolescence, 32(125), 131-141.

Jonassen, D., Davidson, M., Collins, M., Campbell, J., \& Haag, B. B. (1995). Constructivism and computer-mediated communication in distance education. American Journal of Distance Education, 9(2), 7-26. https://doi.org/10.108o/o8923649509526885

Katranc1, Y., \& Bozkuş, F. (2014). Learning styles of prospective mathematics teachers: Kocaeli University case. Procedia - Social and Behavioral Sciences, 116, 328-332.

https://doi.org/10.1016/j.sbspro.2014.01.216

Kolb, A. Y., \& Kolb, D. A. (2005). Learning styles and learning spaces: Enhancing experiential learning in higher education. Academy of Management Learning \& Education, 4(2), 193-212. https://doi.org/10.5465/AMLE.2005.17268566

Kolb, D. A. (1984). Experiential learning. Prentice Hall. http://www.amazon.fr/dp/Boo71ML6FI Kolb, D. A., Rubin, I. M., \& McIntyre, J. M. (1971). Organizational psychology: An experiential approach. Prentice Hall.

Kolb, D. A. (1999). Learning style inventory, Version 3. Hay Resources Direct.

Komarraju, M., Karau, S. J., Schmeck, R. R., \& Avdic, A. (2011). The Big Five personality traits, learning styles, and academic achievement. Personality and Individual Differences, 51(4), 472-477. https://doi.org/10.1016/j.paid.2011.04.019

Kurbanoğlu, S., \& Akkoyunlu, B. (2008). Learning styles of the students of the department of information management. Turkish Librarianship, 22(3), 296-307.

Kuzgun, Y., \& Deryakulu, D. (2006). Bireysel farklılıklar ve eğitime yansımaları [Individual differences and their reflections on education]. In Y. Kuzgun \& D. Deryakulu (Eds.), Eğitimde Bireysel Farklılıklar [Individual differences in education] (2nd ed., pp. 1-11). Nobel Yayın.

Özdemir, N., \& Kesten, A. (2012). The learning styles of prospective social studies teachers' and the relationship between demographic characteristics. Journal of Graduate School of Social Sciences, 16(1), $361-377$.

Pinto, J. K., \& Geiger, M. A. (1991). Changes in learning-style preferences: A prefatory report of longitudinal findings. Psychological Reports, 68, 195-201. https://doi.org/10.2466/PRo.68.1.195-201 Rakoczy, M., \& Money, S. (1995). Learning styles of nursing students: A 3-year cohort longitudinal study. Journal of Professional Nursing, 11(3), 170-174. https://doi.org/10.1016/S8755-7223(95)80116-2 Reynolds, J., \& Gerstein, M. (1992). Learning style characteristics: An introductory workshop. The Clearing House, 66(2), 122-126. 
Ristori, C. A., Eberman, L. E., Tripp, B. L., \& Kaminsky, T. W. (2011). Athletic training student learning style. International Journal of Athletic Therapy and Training, 16(2), 33-37.

Şimşek, A. (2006). Öğrenme biçimi [Learning style]. In Y. Kuzgun \& D. Deryakulu (Eds.), Eğitimde Bireysel Farkliliklar (2nd ed., pp. 97-138). Nobel Yayın.

Stradley, S. L., Buckley, B. D., Kaminski, T. W., Horodyski, M., Fleming, D., \& Janelle, C. M. (2002). A nationwide learning-style assessment of undergraduate athletic training students in CAAHEPaccredited athletic training programs. Journal of Athletic Training, 37(4 suppl), 141-146.

Uzuntiryaki, E. (2007). Learning styles and high school students' chemistry achievement. Science Education International, 18(1), 25-37.

Yalız, D., \& Erişti, B. (2010). Learning styles of students in the Department of Physical Education and Sports Teacher at Anadolu University. Celal Bayar University Journal of Physical Education and Sport Sciences, 4(4), 156-163.

Yaşar, Ş. (1998). Yapısalcı kuram ve öğrenme-öğretme süreci [Structuralism and learning-teaching process]. Anadolu Üniversitesi Eğitim Fakültesi Dergisi, 8(1-2), 68-75.

Yazıcılar, Ö., \& Güven, B. (2009). The effects of learning style activities on academic achievement, attitudes and recall level. Procedia - Social and Behavioral Sciences, 1(1), 2578-2583.

https://doi.org/10.1016/j.sbspro.2009.01.455

\section{Biographical note}

Ceyhun Alemda $\breve{G}, \mathrm{PhD}$, is an assistant professor in the field of physical education and sports on the Faculty of Sport Sciences at Trabzon University, Turkey. He focuses on the professional development of physical education teachers in terms of educational psychology. His research interests include teaching and learning, epistemological beliefs and academic self-efficacy in teacher education. 